\author{
Michal Zajfert \\ Dr \\ Instytut Nauk Ekonomicznych PAN \\ mzajfert@inepan.waw.pl
}

DOI: $10.35117 / A$ ENG $18 \quad 0801$

\title{
The influence of qualitative factors in urban public transport in Poland on the substitution of means of transport
}

\begin{abstract}
The subject of the article is public transport in urban areas in Poland. The article presents the impact of demand and supply factors on public transport. The time range covers the period of the last 16 years, 2001-2016. The aim of the work is to analyze the qualitative factors characterizing public transport services, which allows an attempt to identify those which seem to have a key impact on creating communication preferences of the residents. The article concludes with a presentation of the instruments available to forward the desired substitution of individual transport by public transport.
\end{abstract}

Keywords: Public transport; Urban transport; Public utilities

\section{Changes in demand for agglomeration transport}

The urban agglomerations are made up of large cities together with the surrounding urbanized areas with a dominant non-agricultural function, strong functional and spatial relationships with these cities, while villages located in these areas, due to the ongoing suburbanization, actually become suburban settlements [3]. As a result, it is difficult to provide an unambiguous definition defining the boundaries of the agglomeration. Agglomeration transport includes intensive transport both in large cities (in the case of Poland, this applies to the majority of voivodship cities) and in their immediate vicinity (i.e. within a radius of 10-20 $\mathrm{km}$ around their borders), mainly providing access to the centers of these agglomerations.

The analysis of the size and nature of agglomeration transport changes is limited by the availability of statistical data. Therefore, the assumption was made that agglomeration transports are those that are implemented by urban transport in Poland [16] and operated by those railway companies whose business area is limited to urban agglomerations (i.e. SKM Trójmiasto, SKM Warsaw and WKD) [13]. It should also be remembered that transports carried out by SKM Warsaw are also included in the data on public transport, as trains of this carrier are carried out as part of the ZTM Warszawa ticket system. Of course, agglomeration rail transport is also serviced by other carriers, but it is not possible to determine their size, because the available statistical data are aggregated with the size of regional transport. Such separate agglomeration services operated by rail currently account for a small share of total urban transport, however, in the analyzed period their share increased from $1 \%$ to $1.9 \%$, which confirms the dynamic growth of their functions in the urban transport system. 


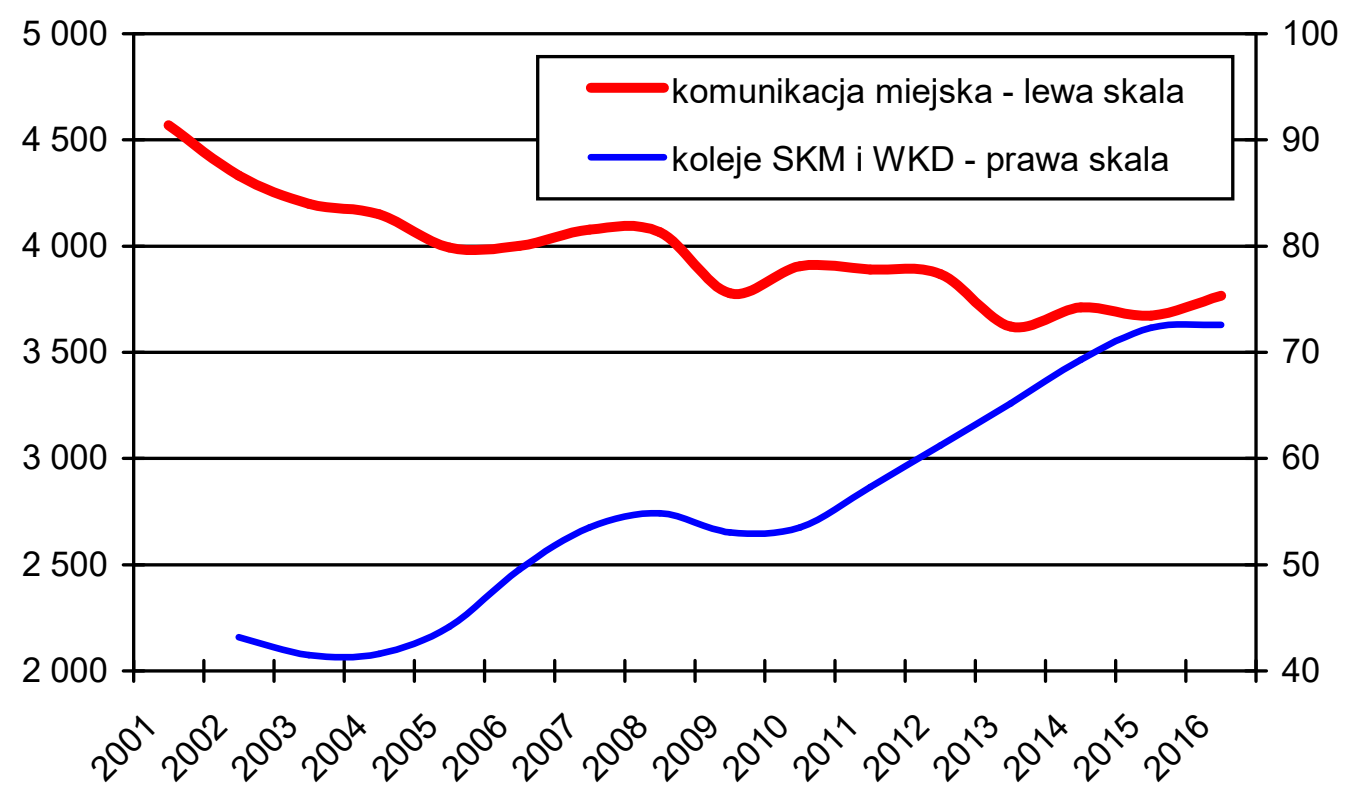

1. Agglomeration transport [mIn pas./year]

Source: Transport - results of operations, Central Statistical Office, Warsaw 2002-2016,

Statistics of passenger rail transport - UTK

The volume of agglomeration services handled by public transport presented in Figure 1 in 2001-2013 decreased by 21\%. However, since 2013, this negative trend has been slowed down, by 2016 there was a slight increase in these transports by $4 \%$. At the same time, in the entire analyzed period (2002-2016) agglomeration rail transport increased by as much as $68 \%$, which is largely the result of the dynamic development of the Fast Urban Railway in Warsaw. In the same period (2005-2016), the transports of Koleje Mazowieckie increased by $52 \%$, they were implemented in an area partially overlapping with SKM Warsaw, so its development did not take place at the expense of Koleje Mazowieckie [13]. An attempt to diagnose the causes of visible negative changes in demand requires the assessment of the supply of public transport services. GUS statistical data allow estimating their availability only on the basis of the following measures:

- total length of communication lines (the sum of distances between the extreme points of the course of all communication lines.);

- total transport work (the product of the number of vehicles started and the length of the route covered by each of them);

- total rolling stock capacity (number of seats and standing in vehicles).

Changes in the supply factors of urban transport, which took place in 2001-2016, are presented in Figure 2. 


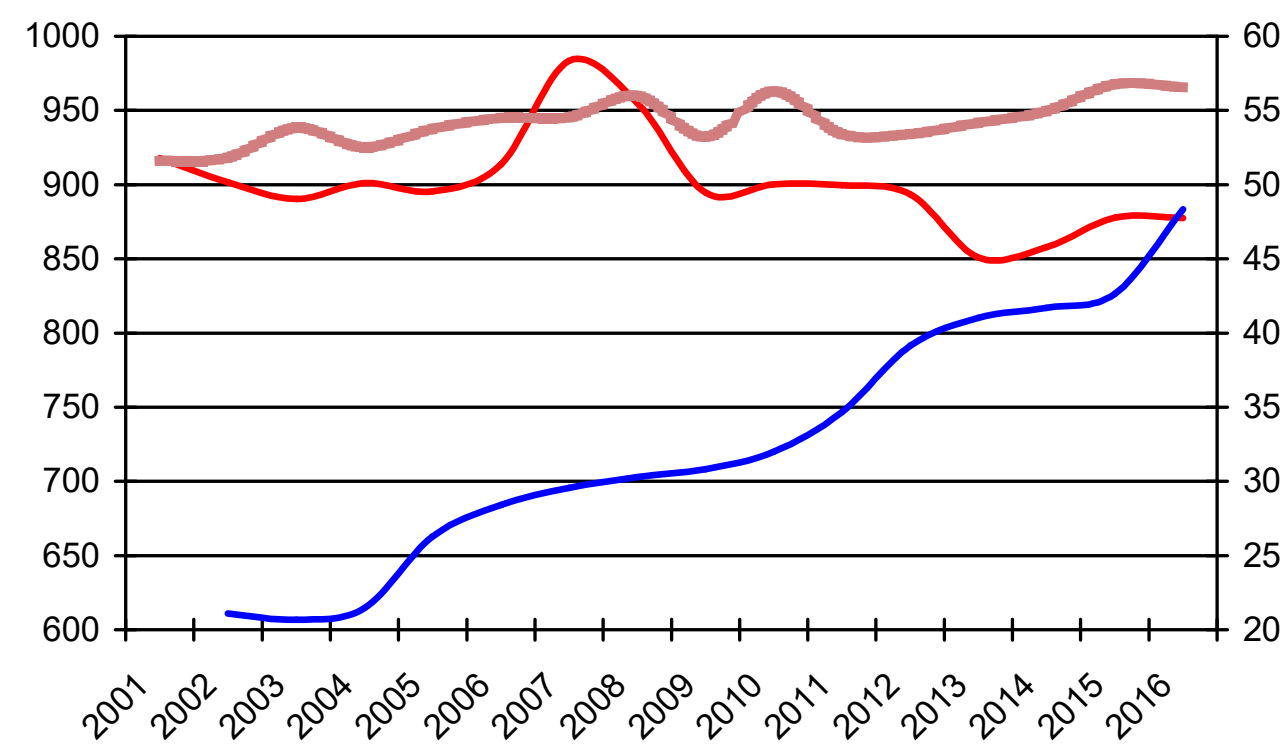

\footnotetext{
_łączny przebieg poj. kom. miejskiej [mln wozokm] - lewa skala

łączna długość linii kom. miejskiej [tys.km] - prawa skala

łączny przebieg poc. aglomeracyjnych [mln wagonokm] - prawa skala
}

\section{Supply of agglomeration services by public transport}

Source: Transport - results of operations, Central Statistical Office, Warsaw 2002-2016

Over the last 16 years, the total length of the line has increased by $10 \%$. This can be interpreted as striving to better adapt the network of communication networks to changing transport needs due to the expansion of urban agglomeration areas and their suburbanization by extending and launching new lines. However, in the same period, the total transport work (i.e. the product of the number of public transport vehicles running and the distance traveled by each of them) dropped by $4.4 \%$. It is worth adding here that the majority, as much as $78 \%$ of this transport work was carried out by buses and in the analyzed period this share practically did not change [16]. The size of the operational work [VKT] performed by trams is somewhat distorted due to the gradual replacement of $105 \mathrm{Na} / 805 \mathrm{Na}$ type two-car type trains, counted as two cars by multi-unit single-city trams. A detailed comparison of changes in supply and demand shows that in 2001-2006 the average supply of public transport services was quite stable and the drop in demand at that time translated into a fall in the average filling of vehicles. A significant increase in the supply by $11 \%$, which took place in 2005-2007, increased the demand, however disproportionately to a lesser extent. In the next two years, despite the limited supply due to the economic crisis, transport remained stable. As a result, the average filling of vehicles at this time increased slightly. In the following years, the average filling remained stable (see Figure 3).

The simultaneous increase in the length of the line and the decrease in transport performance on these lines means that, as a result, the average frequency of running of vehicles decreased by $13 \%$, which indicates a progressive deterioration of the accessibility of public transport. It seems important to determine what the frequency change really means for the average passenger. First of all, it should be noted that formally different communication lines often serve the same route, so from the passenger's point of view, they are only different variants of a given line. This fact takes into account the total length of routes served by public transport rather than lines following them. However, since 2008, the data presented by the Central Statistical Office does not include this size anymore. A comparison of the available data for the years 2001-2007 shows that one route was served on average by two lines and 
this amount did not change much during this period. Therefore, it can be assumed that this relationship was maintained until 2016. It was also assumed that on a given route the lines run throughout the day from 5 to 23. The above assumptions allowed to determine the average time interval between consecutive departures of public transport vehicles on a given route, which was presented in graph 3. At the same time, vehicles were filled with the assumption that in the whole analyzed period the average public transport passenger covered it with a distance of $5 \mathrm{~km}$. In addition, the same graph shows analogous sizes for agglomeration railways. Due to the availability of data, the designated filling of trains takes into account the different distance traveled by travelers in particular year.

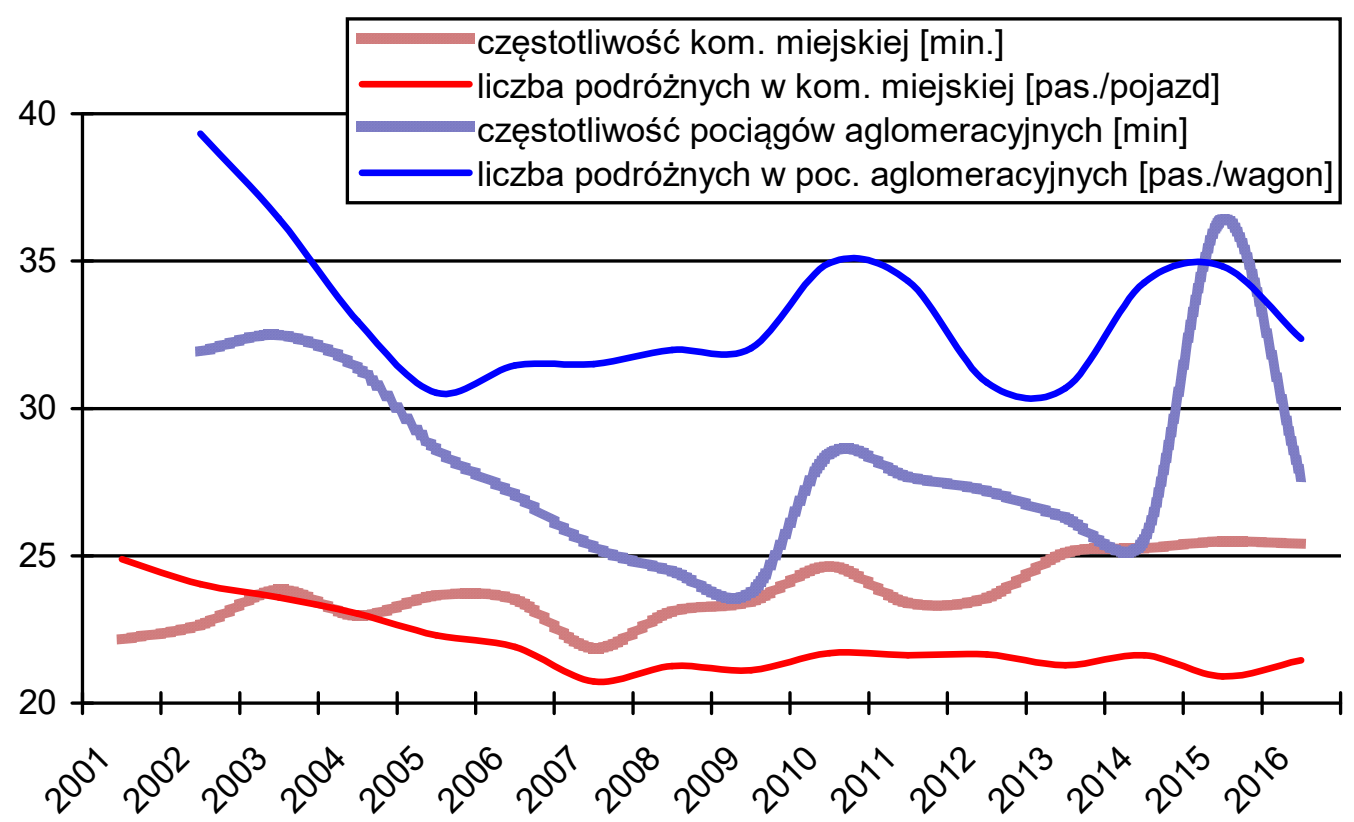

3. Average frequency of departures and number of travelers in public transport vehicles Source: own calculations based on Transport - results of operations, Central Statistical Office, Warsaw 20022016, Statistics of passenger rail transport - UTK, Report of the Management Board of SKM 20062014. When calculating the average filling of trains for SKM Warszawa, known quantities of the work performed were used [VKT], for WKD it was assumed that each train $=4$ wagons (2xEN94), for SKM Trójmiasto it was assumed that each train had electric traction $=6$ wagons (2xEN57), for diesel traction $=3$ wagons $(S A 136 c c)$.

Figure 3 allows indicating that in the last 16 years the frequency of public transport decreased slightly - the average time interval between consecutive departures of vehicles on a given route increased from 22 to 25 minutes. During the same period, the frequency of agglomeration rail increased - the average time interval decreased from 32 to 28 minutes, while in 2009 it was the lowest and amounted to 24 minutes. The apparent change in the frequency of running agglomeration trains in 2015 is the result of the opening of the Pomeranian Metropolitan Railway in the fourth quarter because the calculation includes operational work for the whole year and the length of the network on the last day of a given year. A relatively small change in the average frequency of public transport vehicles indicates that this measure of supply cannot explain the significant decline in the demand for public transport services seen in the country.

In the analyzed period, the average filling in a public transport vehicle decreased from 25 to 21 passengers, and in the agglomeration railway car's train's passenger fell from 39 to 32 passengers. With regard to agglomerations, there is a correlation between the change in the 
frequency of departures and the filling of trains. Indirectly, this indicates that the growing share of agglomeration railway (see Figure 1) is to a large extent a consequence of a significant increase in the supply of services of this means of transport, measured among others performed by operational work (see Figure 2).

In 16 years, the total capacity of the urban transport fleet (the number of seats and standing in vehicles) decreased slightly by 4\% [16]. This is not a reason for the drop in demand, in fact, it indicates the adjustment of technical parameters of the rolling stock to actual needs and the departure in many cities from the once common practice of servicing all lines with rolling stock of equal capacity. An important factor improving the offer an image of public transport is escaping the statistics of the Central Statistical Office (GUS), but clearly visible on the streets of cities ongoing exchange of rolling stock for modern and passengerfriendly.

The perspective of the last 16 years (2001-2016) allows indicating factors contributing to the fall in demand for public transport services in Poland, which is definitely stronger than the rate of supply reduction. Its source is the abandonment of public transport mainly for reasons attributable to the residents, which is a consequence of, among others:

- the dissemination of individual motorization, which is also an indicator of material status;

- systemic changes in society and the economy resulting from technical progress, increase in the wealth of the society and economic development of the country;

- suburbanisation - the urban inhabitants move to the periphery and suburban zones without efficient public transport;

- location of large shopping centers in the periphery of cities focused on motorized customers (parking lots, size of purchases made, etc.).

The dynamic development of individual motoring is a key factor in the decline in interest in public transport. As a result of technical progress, increased wealth and other factors, including Poland's accession to the European Union, the purchase and operating price of a passenger car are decreasing. As a result, the level of motorization is growing much faster than the income of the population. In the last 16 years, the number of registered passenger cars per 1 inhabitant has increased by as much as $107 \%$, so more than twice. As a result, one car has an average of two Polish residents, which in practice means that most households now have their own car [16]. This is confirmed by the results of the surveys carried out. According to them, in the agglomeration of Bydgoszcz and Torun as early as $2010,68.5 \%$ of residents had a car in their household [17], while in 2015 in Gdynia, the share of such farms was $72 \%$. $[4]$.

The dynamic development of individual transport. As a result of technical progress, increased wealth and other factors, including Poland's accession to the European Union. As a result, the level of motorization is growing faster. In the last 16 years, the number of registered passenger cars per 1 inhabitant has increased by as much as $107 \%$, so more than twice. As a result, one of the most common households has their own car [16]. This is confirmed by the results of surveys carried out. According to them, in the agglomeration of Bydgoszcz and Torun as early as $2010,68.5 \%$ of residents had a car in their household [17], while in 2015 in Gdynia, the share of dry farms was 72\%. This determines an efficient substitution of the means of transport - resignation by some residents from the use of their own passenger car, despite the fact that they have one. Indirectly, this is indicated by the fact that in the last 16 years, the number of cars registered in Poland has more than doubled and public transport services decreased by only $17 \%$, which is also confirmed by other cases described in the literature [5]. The development of road infrastructure, of course, increases the capacity of the street network, however, it is immediately discounted by its residents, which is the result of the occurrence of latent demand. New investments mean that many people who 
have so far resigned from using a car, change their communication behavior and decide to use it [10]. Therefore, any changes in road infrastructure (construction of new streets, widening of existing ones, construction of collision-free intersections, etc.) do not change the overall density and smoothness of traffic in the agglomeration area. The best proof of the fact that traffic congestion in cities is always close to the capacity limit are all unforeseen traffic disruptions due to sudden circumstances (e.g. snowfall, heavy rains, blocking a major street as a result of an accident or water supply failure) that cause unexpected reduction of network capacity roads and, as a result, the communication paralysis of the city. Therefore, arguing for the development of road infrastructure to reduce its congestion remains only wishful thinking. The experience of Western European countries and the United States indicate that increasing the capacity of the road network by expanding the area occupied by streets does not lead to solving this problem [10].

\section{Quality of urban transport}

The condition for the desired substitution of individual transport for collective transport is to ensure its high quality possible. The public quality of public transport is affected by many factors. In the EU report created in 1998, referred to in brief as QUATTRO (Quality Approach in Tendering / contracting Urban Public Transport Operations) [2], they were systematized to include to facilitate their inclusion in procurement processes for public services:

1. Availability of the communication network

1.1. Communication network layout

1.2 Timetable (frequency)

2. Functional availability

2.1 Availability of stops

2.2 Internal connections (transfers)

2.3 Availability of tickets

3. Information system

3.1. Basic information

3.2. Travel information in normal conditions

3.3. Travel information in exceptional conditions

4. Time

4.1 Travel time

4.2. Punctuality and reliability (compliance with schedule)

5. Contact with the customer

5.1 Commitment

5.2. Customer service

5.3 Staff

5.4 Help and support

5.5. Tariff system options

6. Comfort

6.1. Seating and personal space

6.2 Facilities

6.3 Ergonomics

6.4. Driving comfort

7. Security

7.1 Protection against crime

7.2 Protection against accidents

7.3. Emergency situations management

8. Environment

8.1 Pollution 


\subsection{Use of natural resources}

\subsection{Infrastructure}

The specification of the qualitative factors presented above became the basis for the adoption in 2002 by the European Standardization Committee of the norm regulating quality issues in the process of providing public mass transport services, which in 2003 was recognized by PKN as the Polish Standard [12]. Users' assessment of most of the above qualitative factors is relative and difficult to quantify. Therefore, on the basis of available statistical data, it turns out that it is impossible to assess the changes in quality and preferences that have been decisive in the recent years in choosing the means of travel. The difficulty is already determining the impact (rank) of each of them on the decisions made by the inhabitants of the agglomeration. However, the available results of a series of surveys carried out in recent years in various agglomerations allow an attempt to determine the weight of qualitative factors included in these studies. The table 1 summarizes the rank and satisfaction rating set as the weighted average number of questionnaires for the results obtained in three studies of the quality of public transport services in Kielce in 2014 (sample of 496 people) [8], in the city in the province. Lublin in 2015 (sample of 91 people) [6] and in Białystok in 2011 (sample of 60 people) [9]. For the latter study, the significance of individual parameters of the quality of public transport services was estimated indirectly, considering the most important for which the lowest share of indications determining their quality was irrelevant was the most important.

Tab. 1. Evaluation of the quality of transport services of public transport passengers

\begin{tabular}{|l|l|l|}
\hline Rank & A quality feature & $\begin{array}{l}\text { Satisfaction } \\
\text { rating on a scale } \\
\text { of 1-5 }\end{array}$ \\
\hline 1 & Punctuality & 3,66 \\
\hline 2 & Reliability & 2,85 \\
\hline 3 & Availability of the communication network & 3,32 \\
\hline 4 & Frequency & 3,53 \\
\hline 5 & Direct connectivity & 3,60 \\
\hline 6 & Time of travel & 3,15 \\
\hline 7 & Ticket price & 2,81 \\
\hline 8 & Travel safety & 3,64 \\
\hline 9 & Information on vehicles and at stops & 3,85 \\
\hline 10 & Convenience of travel & 3,41 \\
\hline
\end{tabular}

Source: own study based on [6] [8] [9]

The respondents rated the lowest price for the trip (2.81 on a scale of 1-5) and reliability (2.85). The second of these factors is simultaneously perceived as one of the most important for passengers, which indicates the need for urban transport organizers to pay special attention to ensuring high traffic reliability. For other qualitative factors, the obtained score was even and can be summarized as quite good. Analysis of the average rank of individual factors clearly indicates that for travelers the most important are those that affect the predictability and total travel time of public transport (i.e. taking into account the time of arrival and waiting for the vehicle) - the six first factors indicated by the respondents. The limitation of this analysis is the occurrence of obvious feedback - the respondents at the time of the survey used public transport precisely because they were sufficiently accessible from their point of view. This relativity of assessment makes it difficult to assess how this access was perceived by the entire population of urban agglomerations. 
Another survey referred to here was carried out in 2014 on a sample of 81 urban transport users in Warsaw. Their important value is the formulation of questions that were directly aimed at identifying the reasons why residents decided to use public transport. Choosing between public and individual communication among the factors taken into account by the respondents as the most important, they indicated the cost of travel $(38 \%$ of indications) and its time (28\%). On the other hand, among the factors that prompted residents to use public transport, aside from the obvious (no car 27\%), 40\% of indications were those associated with lost time (large congestion, parking difficulties and speed of travel) and 21\% of indications concerned a smaller cost compared to individual transport [15]. All the studies presented so far have been carried out among people using public transport at the time of their survey. They could not, therefore, indicate the reasons for the reasons why a given person does not use public transport. However, it turns out that similar conclusions result from the published results of research carried out in 2015 among a random sample of 2.5 thousand. Gdynia's residents. As much as $44.5 \%$ of the indicated factors determining the choice of a passenger car instead of public transport resulted from the difference in the total travel time (shorter time of car travel, no need to wait for a vehicle, change, get to and from the bus stop). At the same time, $25 \%$ of the factors determining the choice of public transport indicated by the respondents resulted from the higher cost of using their own car (the need to pay a parking fee and a lower cost of travel by public transport) [4].

Also in a survey carried out in 2010 on a random sample of 4105 inhabitants of the Bydgoszcz-Torun agglomeration similar results were obtained. Among respondents who do not use public transport, the incentive to choose a car, in addition to convenience (35\%), was the travel time. The total significance of the indicated factors related to it amounted to $42 \%$ (no need to wait, shorter travel time by car, no need to reach and from the bus stop). Among respondents with a car and using public transport, the motivation to choose was to compare the price of the trip. The total significance of the indicated factors related to it amounted to $25 \%$ (lower cost of travel by public transport, parking fees, integrated ticket). Among the respondents declaring their willingness to abandon public transport, the decisive parameter prompting to change this decision and further use of public transport was the travel time. The total significance of the indicated factors related to it was 53\% (higher frequency of running, direct connections, higher speed of travel, closer to stops, difficulty with parking, separate lanes for buses), and only $16 \%$ is a derivative of the comparison of the travel price [1].

The applied reduction of the impact of various qualitative factors only to the resulting measurable value of lost time or costs is, of course, a kind of simplification. Striving for a high standard in terms of other qualitative factors is also very important but not sufficient condition for the substitution of individual transport for public transport. Therefore, the adoption of such a simplification allows indicating the scope of these factors, in which it is possible to introduce changes that may bring the greatest results. The results obtained in all the studies presented indicate that for transport preferences of residents, the factors that translate into the measurable benefits achieved by them, which allow reducing the costs of lost time (also due to reliability) and travel costs, are decisive. At the same time, the assessment of the general standard of public transport and its safety is satisfactory, which coincides with the visible favorable changes that currently occur in virtually all cities throughout Poland. The successively mentioned rolling stock is modern and aesthetic, the remaining qualitative factors difficult to quantify also appear to be at a sufficiently good level. At the same time, as indicated by the results of various surveys presented above, the impact of these qualitative factors on communication preferences turns out to be of relatively minor importance to residents. This allows the assumption that currently, the key condition for substituting individual transport for public transport is to meet the following inequality including measurable cost components:

$$
t_{\text {sam }} * A+P_{\text {paliwo }}>t_{\text {tr.publ. }} * B+P_{\text {bilet }}
$$


$t_{\text {sam }} \quad$ time lost while driving and parking;

$A$ factor that determines the material value of driving time;

$P_{\text {paliwo }}$ the cost of traveling by car;

$t_{\text {tr.publ }}$ time lost while using public transport;

$B$ factor that determines the material value of the time of driving a public transport vehicle;

$P_{\text {bilet }} \quad$ the cost of a ticket for transport by public transport.

The cost lost time coefficients listed in the above-mentioned inequality are a subjective and individual measure. This is influenced by even private preferences - some of them enjoy driving a car, which in the above inequality contributes to lowering the value of factor A. For others, for example, the ability to read during travel is more pleasant, which in turn may reduce the value of factor $\mathrm{B}$. Of course, this value decreases also improving the broadly understood comfort of using public transport. The length of time lost when using public transport is made up:

- an average time of arrival at the stop, which is a derivative of the communication network (according to [2] factor 1.1.), its approximate measure can be taken for the density of the communication network (length of the line $[\mathrm{km}] /$ city area) $\left[\mathrm{km}^{2}\right]$ ),

- waiting time for the vehicle, also during transfers, i.e. frequency of public transport vehicles [min], which results from the construction of the timetable (according to [2] factors 1.2 and 2.2.);

- time lost due to unplanned vehicle delay due to traffic congestion or malfunction (punctuality and reliability, according to [2] factor 4.2.);

- travel time (by [2] factor 4.1.).

Survey carried out in 2009 on a sample of 5,000 inhabitants of 5 cities of eastern Poland (Białystok, Kielce, Lublin, Rzeszów, Olsztyn) present a number of reliable information on transport residents' preferences and their travel time by public transport:

- for $55 \%$ of residents, the main means of transport is a passenger car;

- $74 \%$ of residents use urban public transport, including $27 \%$ of the population, which is the main means of transport;

- average time of arrival at the bus stop was $4.95 \mathrm{~min}$, therefore the average distance to the bus stop was $0.4 \mathrm{~km}$;

- average waiting time for the vehicle was 8 minutes;

- the average travel time by public transport was 23 minutes;

- $58 \%$ of the total number of courses was delayed compared to the timetable, including 53\% during peak hours;

- the average delayed rate was 11 minutes, so the average delay for each exchange rate was 6.38 minutes;

- the operational speed of public transport vehicles was $16.0 \mathrm{~km} / \mathrm{h}$, so the average travel distance (product of speed and time) including the delay was $4.4 \mathrm{~km}$;

- $91 \%$ of passengers traveled without changing [17].

The above data set allows estimating the average total travel time when using public transport, which in 36 cities was 36 minutes, distance traveled $5 \mathrm{~km}$ and the average cost of such a trip was $2.62 \mathrm{PLN}$. It has been estimated as the arithmetic average of one-off and monthly tickets prices in Białystok, Lublin, and Olsztyn, assuming that the holder of a monthly ticket during that time makes 40 journeys, i.e. two journeys each working day. However, the cost of driving your own car can be estimated taking the fuel consumption $101 /$ $100 \mathrm{~km}$ reflecting its significantly increased consumption when starting the internal combustion engine, which is important when traveling for short distances, and takes into account the other costs of using the car (eg inspections, insurance, etc. ). With a distance of 5 $\mathrm{km}$ and an average fuel price of 4.50 PLN / 1, the cost of one trip amounted to 2.25 PLN, so it 
was almost equal to the price for the ticket. However, this situation is fundamentally changed if the use of your own car entails the need to pay a parking fee.

he actual average speed while driving in the center of the 10 largest Polish agglomerations in 2016 was $29.2 \mathrm{~km} / \mathrm{h}$ [11]. This means that the time needed to cover the aforementioned distance of $5 \mathrm{~km}$ was on average about 10 minutes. In addition to the time lost on the trip itself, it was necessary to take time to get to the car, later parking and then reaching the actual destination. It can be assumed that the sum of this time was also about 10 minutes, so the total time of travel by car was about 20 minutes. and it was much shorter compared to public transport.

The presented results coincide with those obtained during the aforementioned research carried out in 2015 in Gdynia. In the light of these results, the time of urban travel to a workplace or study in the door-to-door relationship was on average $20.11 \mathrm{~min}$. using a car, while for public transport $37.26 \mathrm{~min}$. [4] On the one hand, it confirms the correctness of the adopted assumptions and on the other indicates that the results obtained seem to reflect the actual situation in all major cities in Poland.

The basic factor determining the choice of a passenger car instead of public transport indicated by the respondents was greater convenience (better driving conditions). It was indicated by $24 \%$ of respondents from Gdynia [4] and $35 \%$ of respondents from the Bydgoszcz-Toruń agglomeration [1]. Obvious technical differences between a passenger car and a public transport vehicle mean that the possibilities to reduce the impact of this factor are small. However, changes in other areas described by other factors indicated by the respondents may affect communication preferences and lead to limiting the use of the car.

\section{Summary}

The above-described conditions for all four cost components of inequality conditioning the substitution of individual transport for public transport. Analysis of the qualitative factors reflecting them leads to the conclusion that the size of each of these components is the responsibility of the city as both an organizer of public transport and a road infrastructure manager:

- reducing the cost of time lost when using public transport is possible, among others by increasing the share of rail transport moving on separate tracks, increasing the length of bus lanes (dedicated belts for buses), introducing the actual priority of public transport at intersections or increasing the frequency of running public transport vehicles;

- changing the cost of time lost while driving and parking is possible by limiting the capacity of the road system as a result of increasing the priority of public transport, calming and slowing down traffic or limiting the number of parking spaces in city centers;

- increasing the cost of car travel is possible by increasing and sealing paid parking zones in city centers, increasing parking fees or introducing car entry fees into the strict center area;

- the city's influence on public transport costs is obvious, as part of this it is possible to differentiate these costs depending on the place of tax collection (registration) by the passenger or regular use of public transport.

The above list indicates a wide range of available tools for shaping the desired communication behavior among its residents. It allows to limit external costs caused mainly by individual transport but also public transport, and at the same time enables charging external car users with passenger cars [7]. The use of some of these instruments, especially at the time of their implementation, may be related to the dissatisfaction of some residents. However, as numerous studies show, the introduction of beneficial changes in relation to other cost components in return makes that the resulting positive effects become perceived and accepted by the residents [10] [14] [18]. 


\section{Source materials}

[1] Badanie preferencji i zachowań komunikacyjnych mieszkańców aglomeracji Bydgosko Toruńskiej, Załącznik do Zintegrowany Program Rozwoju Transportu publicznego dla aglomeracji bydgosko-toruńskiej, ze szczególnym uwzględnieniem bydgosko-toruńskiego obszaru metropolitarnego na lata 2010-2015, TRAKO, 2010

[2] Common work Quattro/CEN TC320 WG5, Final Report Synthesis and recommendations, Contract $\mathrm{N}^{\circ}$ UR-96-SC-1140, Transport RTD Programme of the EU's 4th Framework Programme for Research, technological Development and Demonstration, 1998

[3] Czyż T., Koncepcje aglomeracji miejskiej $i$ obszaru metropolitalnego w Polsce, Przegląd Geograficzny 4/2009 (81) s. 448

[4] Hebel Katarzyna, Wołek Marcin, Wyszomirski Olgierd, Rola samochodu osobowego w podróżach miejskich mieszkańców Gdyni w 2015 roku w świetle wyników badań marketingowych, Przegląd Komunikacyjny nr 2/2017, s.21

[5] Holmgren Johan, An analysis of the determinants of local public transport demand focusing the effects of income changes, European Transport Research Review 5/2013 s.101-107

[6] Kowalik K., Sykut B., Tomporowski A., Szyszko G., Hermaniuk T., Perduta-Dybiec A., Cele transportu zbiorowego $w$ wybranym mieście województwa lubelskiego $w$ ocenie grup użytkowników, Autobusy nr 6/2016 s.1713

[7] Koźlak A., Ekonomika transportu, Teoria i praktyka gospodarcza, Wydawnictwo Uniwersytetu Gdańskiego, Gdańsk, 2008, s.122

[8] Mikulska A., Starowicz W., Analiza preferencji $i$ satysfakcji pasażerów transportu publicznego $w$ Kielcach, Transport miejski i regionalny nr 3/2015 s.25

[9] Milenkiewicz B.J., Halicka K., Ocena jakości ustug w transporcie zbiorowym na przykładzie Białostockiej Komunikacji Miejskiej, Economy and Management nr 4/2011s. 83-84

[10] Nosal, K., Starowicz W., Wybrane zagadnienia zarządzania mobilnościa, Transport Miejski i Regionalny, 2010, nr 3.

[11] Raport - Ranking najwolniejszych polskich miast - wiosna 2017, http://korkowo.pl/raport/ranking-najwolniejszych-polskich-miast-wiosna-2017-705 (dostęp 30.01.2018)

[12] Starowicz W., Charakterystyka polskiej normy „Jakość uslug w publicznym transporcie pasażerskim”, Technika Transportu Szynowego nr 9/2004 s.29

[13] Statystyka przewozów pasażerskich, dane eksploatacyjne, Urząd Transportu Kolejowego, www.utk.gov.pl/pl/raporty-i-analizy/analizy-i-monitoring/statystyka-przewozow-pa

[14] Stoeck Tomasz, Analiza porównawcza preferencji i zachowań komunikacyjnych studentów oraz pracowników dojeżḋających do Zachodniopomorskiego Uniwersytetu Technologicznego w Szczecinie, Przegląd Komunikacyjny 5-6/2011

[15] Świaniewicz K., Rokicki T., Rozwój komunikacji miejskiej w Warszawie w opinii jej użytkowników, Ekonomika i Organizacja Logistyki, nr 1/2016 (2), s.89-98

[16] Transport, Wyniki działalności w latach 2001-2016 r., GUS, Warszawa. 2002-2017

[17] Ustalenie sytuacji wyjściowej w odniesieniu do Dziatania III.1 PO RPW-systemy miejskiego transportu zbiorowego, Raport końcowy, Warszawa, 2009

[18] Zych Franciszek, Transport w miastach - problemy modernizacji, osiagnięcia miast $i$ oceny odbiorców ustug transportowych, ZMP, SAS, Kraków 2011. 